\title{
A nemkívánatos események általános okai és kezelési lehetőségei az egészségügyben
}

\author{
Eredmények és tanulságok a hazai NEVES jelentési \\ és tanulórendszerbe érkezett jelentések alapján
}

\author{
Belicza Éva dr. ${ }^{1,2}$. Dombrádi Viktor dr. ${ }^{1}$ \\ Mikesy Gergely dr. ${ }^{1}$. Sinka Lászlóné Adamik Erika ${ }^{1,2}$
}

${ }^{1}$ Semmelweis Egyetem, Egészségügyi Közszolgálati Kar, Egészségügyi Menedzserképző Központ, Budapest, ${ }^{2}$ NEVES Egyesület a Betegbiztonságért, Budapest

\begin{abstract}
Bevezetés: Hazánkban 2007-ben indult el a NEVES (NEm Várt ESemények) rendszer, amelybe az eltelt időszakban több mint 26,5 ezer nemkívánatos eseményre vonatkozó jelentés érkezett. A jelentések feldolgozásával hét témakörben készültek oki kutatások és ajánlások a feltárt okok megelőzésére.

Célkitüzés: Az oki kutatások eredményei alapján a hazai ellátási gyakorlatban meglévő legfontosabb, nemkívánatos eseményhez vezető általános okok azonosítása és ajánlások megfogalmazása a kezelésükre.

Módszerek: Témakörönként végeztünk szakirodalmi kutatást a lehetséges okok és kezelési lehetőségek feltárására. Leíró statisztikai elemzéseket alkalmaztunk a jelentések adatai alapján az összefüggések megállapítására, majd Ishikawa-diagrammal kerestük az alapvető okokat. Fókuszcsoportos megbeszélések alapján gyüjtöttünk lehetséges megoldásokat. A munkacsoportok eredményeiből összefoglaló táblázatokat készítettünk.

Eredmények: Kilenc fö oki csoport volt meghatározható: a szabályozás, szabálykövetés, a végzett tevékenységek hiányosságai; az eseményekből való tanulás hiánya; az oktatás, a humánerőforrás, a kommunikáció és dokumentálás, illetve az eszközhasználat, infrastruktúra problémái. A megoldási javaslatok hat csoportba sorolhatók: a szabályozások kialakításával és a gyakorlati alkalmazás elérésével kapcsolatos teendők; az oktatások megszervezése és lebonyolítása; beszerzés a szükségletek alapján; a kommunikáció fejlesztése; tanulás a hibákból, nemkívánatos eseményekből; motivációs eszközök alkalmazása.

Következtetés: Az előforduló nemkívánatos események oki szerkezete hasonló mintázatú, ezért az eseményekről szóló információk gyưjtése, elemzése alapján megállapíthatók a legfontosabb kezelendő okok. Az országos szintű elemzések kiinduló pontot jelenthetnek a helyi sajátosságok és fejlesztési irányok azonosítására. A kutatások alapján feltárt múködési gyengeségek kiküszöbölésével, kezelésével nemcsak a kutatásba bevont témakörökben, hanem általánosságban is javulhat a betegellátás biztonsága. Ehhez elkötelezett vezetés, a változtatások meghatározáshoz betegbiztonsági ismeretek és szemlélet, illetve változtatási hajlandóság szükséges.
\end{abstract}

Orv Hetil. 2022; 163(6): 236-245.

Kulcsszavak: nemkívánatos esemény, jelentési és tanulórendszer, gyökérokelemzés, betegbiztonságot támogató szervezeti kultúra

\section{Aggregate causes of adverse events and possible methods to mitigate them within healthcare}

\section{Results and lessons learned based on the reports sent to the Hungarian NEVES reporting and learning system}

Introduction: In 2007, the NEVES system started its operation in Hungary. Ever since, more than 26.5 thousand adverse events reports arrived. By analysing these reports, causal research was conducted and recommendations were made to prevent these causes.

Objective: Based on the results of the causal research, the identification of the most important causes of adverse events within the Hungarian healthcare settings, and the creation of recommendations on how to tackle these causes. 
Methods: To identify possible causes and actions that can be made, a literature survey was conducted for each area. Descriptive statistics was conducted to identify possible associations, after which Ishikawa chart was used to search for possible root-causes. Possible solutions were gathered via focus groups discussions. Summary tables were created based on the results of these focus groups.

Results: Nine main groups of causes were identified: regulation; following regulations; shortcomings of activities that should be carried out; not learning from previous events; education; human resources; communication and documentation; the usage of devices; problems with the infrastructure. The recommended solutions can be grouped into six areas: actions regarding the creation and everyday usage of regulations; organising and conducting educations; procurement based on needs; improving communications; learning from mistakes and adverse events; using motivation tools.

Conclusion: The analysis made at the national level can be the basis to identify local circumstances and areas of improvement. This requires dedicated leadership, adequate patient safety knowledge and perspective to achieve changes and willingness to make changes.

Keywords: adverse event, reporting and learning system, root cause analysis, safety culture

Belicza É, Dombrádi V, Mikesy G, Sinka LAE. [Aggregate causes of adverse events and possible methods to mitigate them within healthcare. Results and lessons learned based on the reports sent to the Hungarian NEVES reporting and learning system]. Orv Hetil. 2022; 163(6): 236-245.

(Beérkezett: 2021. július 12.; elfogadva: 2021. augusztus 19.)

\section{Rövidítések}

EFOP = Emberi Erőforrás Fejlesztési Operatív Program; EMK = Egészségügyi Menedzserképző Központ; MATARKA = Magyar Folyóiratok Tartalomjegyzékeinek Kereshető Adatbázisa; MOB = Magyar Orvosi Bibliográfia; NEVES = NEm Várt ESemények; RCA = (root cause analysis) gyökérokelemzés; VEKOP = Versenyképes Közép-Magyarország Operatív Program; WHO = (World Health Organization $)$ Egészségügyi Világszervezet

A 2000-ben közzétett „To err is human” (Tévedni emberi dolog) címú könyv rávilágított az egészségügyi ellátás során előforduló nemkívánatos események jelentőségére és azok következményeire [1]. Mivel ezeknek az eseményeknek több mint kétharmada megfeleló intézkedésekkel elkerülhető lett volna, a könyv szerzői számos lépést javasoltak, amelyek révén csökkenteni lehetne ezek előfordulását. Javaslataik között szerepelt egy olyan országos jelentési és tanulórendszer kialakítása, amely révén vizsgálni lehetne a hibák és a nemkívánatos események előfordulását, okait, és amelynek segítségével azonosítani lehetne a múködóképes és eredményes betegbiztonsági intézkedéseket. A javaslat következményeként 2005-ben az Egyesült Államok törvényhozói létrehoztak egy ilyen jelentési rendszer múködéséhez szükséges jogszabályt [2], valamint ugyanebben az évben az Egészségügyi Világszervezet (WHO) a tagállamait is arra buzdította, hogy alakítsanak ki hasonló jellegú rendszereket [3]. Felismerve ennek lehetséges értékét, 2009-ben az Európai Bizottság is javaslatot tett a betegbiztonság javítását célzó, nemzeti szintű jelentési és tanulórendszerek kialakítására [4]. Ma már az ismert nemzetközi és nemzeti szintű betegbiztonsági ajánlások mindegyike hangsúlyozza a hibákból való tanulás szükségességét és ennek érdekében az országos vagy intézményi szintû́ jelentési és tanulórendszerek kialakítását [5].

2006-ban a WHO és az Egészségügyi Minisztérium felkérte a Semmelweis Egyetem Egészségügyi Menedzserképző Központját (EMK), hogy adaptálja hazai körülményekre a WHO által az előző évben közzétett, a nemkívánatos események jelentési és tanulórendszerére vonatkozó ajánlást [3]. Az EMK a Magyar Kórházszövetség Minőségügyi Szakbizottságának közremúködésével értelmezte az ajánlás elemeit, és nem csupán megfogalmazta a hazai rendszer javasolt jellemzőit, hanem el is indította és azóta is múködteti a NEm Várt ESemények - NEVES - megnevezést kapott jelentési rendszert [6].

A kialakított jelentési rendszer megfelel a WHO ajánlásainak [3]: önkéntes, anonim és szankciómentes, továbbá független szakértői szervezet, az EMK múködteti. A NEVES rendszerbe online felületen keresztül 21, elóre definiált eseményt jelenthetnek regisztráció után az egészségügyi szolgáltatók. A strukturált adatlapok (neves.nevesforum.hu) az adott témakör szakértőinek bevonásával kerültek kialakításra, így tartalmazzák az érintett - a károsodott - személy demográfiai jellemzőit, az esemény helyszínét, körülményeit - beleértve a lehetséges okokat -, valamint az esemény következményeit. Lehetőség van arra is, hogy szabad szöveges formában az esemény jelentője megnevezze azokat az intézkedéseket, amelyekkel véleménye szerint elkerülhető lett volna az esemény kialakulása [7].

A NEVES rendszerbe a 2007-es indulása óta az elemzések megkezdésééig 26,5 ezer jelentés érkezett. A jelen- 
téseknek akkor van értékük, ha az érintett szolgáltatók tanulnak belóle, azaz megértik az események hátterét, és intézkedéseket hoznak a hasonló események megelőzésére, illetve az előfordulás gyakoriságának csökkentésére. Ennek szellemében az EFOP-1.8.0-VEKOP-17, Az egészségügyi ellátórendszer szakmai-módszertani fejlesztése címú, kiemelt pályázati konstrukció keretében a NEVES-jelentések alapján több témakörben végeztünk oki kutatást, és a feltárt okokra támaszkodva ajánlásokat fogalmaztunk meg az események elkerülése érdekében.

\section{Célkitüzés}

Dolgozatunk célja, hogy a NEVES-jelentések oki kutatási eredményei alapján meghatározzuk a hazai ellátási gyakorlatban meglévő azon legfontosabb általános okokat, amelyek nemkívánatos eseményekhez vezethetnek, és ajánlásokat fogalmazzunk meg elkerülésük érdekében.

\section{Módszerek}

$\mathrm{Az}$ oki kutatásokhoz azt a hét témát választottuk ki, amelyek esetében a statisztikai elemzésekhez elegendő jelentés érkezett (1. táblázat). Az elemzések témakörönként külön-külön munkacsoportokban zajlottak. A minőségügy és a betegbiztonság területén járatos, felsőfokú egészségügyi végzettséggel rendelkező munkatársak irányították és végezték a kutatást témakörönként eltérő összetételben (orvos, ápoló, gyógytornász, egészségügyi menedzser, minőségügyi és betegbiztonsági menedzser, egészségpolitikai szakértő). Az aggregált oki kutatás előre meghatározott módszertan szerint történt $[8,9]$ : a jelentések adatainak feldolgozása mellett szakirodalmi áttekintésre és minőségfejlesztési technikák alkalmazására került sor.

A statisztikai elemzéshez a NEVES jelentési rendszerbe az annak indulása óta beérkezett valamennyi adatot exportáltuk. Az utolsó lekérdezés 2020 márciusában

1. táblázat Az országos adatokból végzett oki kutatások témakörei a beérkezett és az elemzett jelentések számával

\begin{tabular}{lccc}
\hline Témakör & $\begin{array}{c}\text { A beérkezett } \\
\text { jelentések } \\
\text { száma }\end{array}$ & $\begin{array}{c}\text { A kizárt } \\
\text { jelentések } \\
\text { száma és } \\
\text { aránya }\end{array}$ & $\begin{array}{c}\text { Az } \\
\text { elemzett } \\
\text { jelentések } \\
\text { száma }\end{array}$ \\
\hline Betegesések & 15245 & $168(1,1 \%)$ & 15077 \\
$\begin{array}{l}\text { Dolgozók bántalmazása } \\
\text { Éles, hegyes eszközök } \\
\text { okozta sérülések }\end{array}$ & 137 & 0 & 137 \\
$\begin{array}{l}\text { Elkóborlás, önkényes távozás } \\
\text { Elmaradt tervezett mútétek }\end{array}$ & 137 & $4(2,9 \%)$ & 133 \\
Nyomási fekély kialakulása & 2614 & $35(1,3 \%)$ & 2579 \\
Újraélesztés & 1199 & $56(4,7 \%)$ & 1143 \\
Mindösszesen & 20506 & $274(1,3 \%)$ & 20232 \\
\hline
\end{tabular}

volt. Az adatok minőségét statisztikai módszerekkel ellenőriztük. Ennek során megvizsgáltuk a jelentőlapok kitöltöttségét, teljességét, az adatmezők logikai kapcsolatait, valamint kerestük az esetleges duplikátumokat. A nem értékelhető adatlapokat kizártuk a vizsgálatból. Az így kapott rekordokból leíró statisztikai elemzéseket és kereszttáblákat készítettünk.

Az egyes témákon belül - relevanciájuk szerint - vizsgáltuk a jelentett eseményeket megelőző történéseket, az események megoszlását napszak, a hét napjai szerint, hol, milyen körülmények között, mely tevékenységek végzése során fordultak elő a leginkább, voltak-e különbségek a feltárt okok esetében a végzett tevékenységek, körülmények, a károsult személyek között nemek, korcsoportok szerint, melyek voltak az ismert következmények. Az újraélesztés témakörében - a többi témakörtől eltérően - nem a végeredményhez, azaz az újraélesztés sikerességéhez vezető okokat vizsgáltuk, hanem az újraélesztési láncban rejlő esetleges gyengeségeket és azok lehetséges okait.

A kapott statisztikai eredmények alapján az események hátterében álló lehetséges kiváltó okok (tervezési hiányosságok és hozzájáruló tényezők) feltérképezéséhez oki kutatást végeztünk Ishikawa-diagramok segítségével a munkacsoportok tagjainak közremúködésével.

Minden munkacsoportban az adott témakörben specifikus, előre meghatározott kulcsszavak segítségével szakirodalmi áttekintést végeztünk. A hazai közlemények esetében a MATARKA és MOB adatbázisokból gyưjtöttük ki a publikációkat. A külföldi szakirodalom áttekintéséhez a PubMed, a Cochrane, az EBSCOhost CINAHL, valamint a Web of Science adatbázisokat használtuk.

A feltárt okok véleményezése, gyakorlati tapasztalatok alapján történő kiegészítése, valamint azok lehetséges megoldási javaslatainak meghatározása érdekében fókuszcsoportos megbeszéléseket is tartottunk, témakörönként két alkalommal. A fókuszcsoportokba az adott szakterületek szakértőit és gyakorló szakembereket kértünk fel, alkalmanként 5-7 résztvevőt. Az összetétel a szakterületeknek megfelelően változott, de általánosan elmondható, hogy a témákban jártas orvosszakmai és szakdolgozói részvétel minden esetben adott volt. Ismertettük számukra az adott témakörben elvégzett oki kutatás eredményeit, melyeket közösen értelmeztünk, és kértük, hogy egészítsék ki azokat saját tapasztalataik alapján, valamint javasoljanak megvalósítható megoldásokat az adott okok kezelésére.

A témakörönként készült tanulmányokban mindezek összegzését az egyes munkacsoportok a szakirodalmi anyagok, a fókuszcsoportok véleménye és saját szakértői tapasztalataik alapján fogalmazták meg.

A munkacsoportokban azonosított potenciális okokat oki csoportokba rendeztük, majd ezekből összefoglaló táblázatot készítettünk. Általános oknak tekintettük azon feltárt potenciális okokat, amelyek valamilyen megfogalmazásban minden tanulmány eredményei között megjelentek. 
Az okok kezelési lehetőségeit az egyes munkacsoportok javaslatai, a szakirodalmi ajánlások és a szerzők saját szakmai ismeretei alapján határoztuk meg.

\section{Eredmények}

A hét témakörben készült elemzések az események hátterében 6-12 oki csoportot azonosítottak. Az egyes oki csoportokon belül a lehetséges alapvető (gyökér-) okok száma 2 és 15 között változott [10-16].
Az egyes témakörökben feltárt lehetséges okok az öszszesítést követően 9 oki csoportba voltak sorolhatók. Ezek a következők (2. táblázat):

\section{Szabálykövetés}

A szabályoktól való eltérés okai között említést érdemel az időhiány, a szabályokkal való egyet nem értés, a szabályok ismeretének hiánya vagy a motiválatlanság azok követését illetően. Következményeként elmaradhatnak

2. táblázat |A NEVES rendszerbe jelentett események kialakulásához vezető általános okok

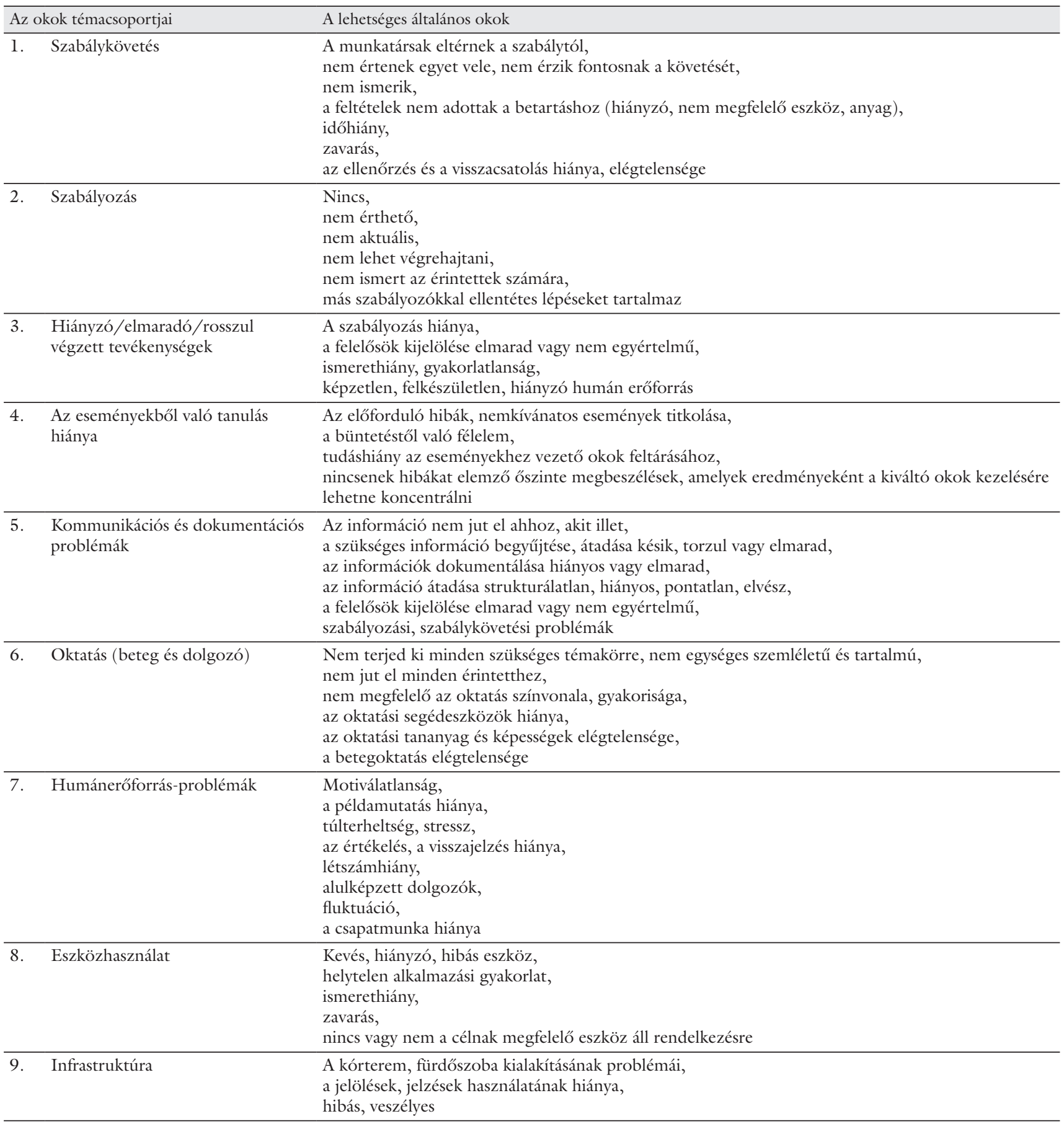


vagy indokolatlanul ismétlődhetnek ellátási események, esetleg nem a beteg számára szükséges diagnosztikai, terápiás vagy ápolási eljárás zajlik, vagy egymásnak ellentmondó tevékenységek történnek a betegekkel.

\section{Szabályozás}

Általános kiváltó okként jelent meg az egyes témakörökben a szabályozókkal kapcsolatban, hogy sokszor hiányoznak, nem érthetôk, nem életszerúek, vagy a végrehajtás feltételei hiányoznak, nem aktualizáltak, vagy nincsenek összhangban a jogszabályokkal, szakmai irányelvekkel, módszertani levelekkel vagy más belső és külső szabályozókkal.

\section{Hiányzó/elmaradó/rosszul végzett tevékenységek}

Általános okként azonosítható, hogy elmaradnak a tevékenységek megfelelő végrehajtásához szükséges vagy a károsodás megelőzését célzó munkafázisok. Az elmaradó, hiányzó tevékenységek között említhető a kockázatok felmérése vagy az ismert kockázatok kezelését célzó prevenciós intézkedések megvalósítása. A szükséges laboratóriumi vizsgálat elmaradása a tervezett mútét halasztását eredményezheti.

\section{Az eseményekböl való tanulás hiánya}

Jellemző probléma, hogy a jelentett események hasonló körülmények között, hasonló okok miatt ismételten előfordulnak. Az intézmények nem elemzik az események okait, így az alapvető okok nem kerülnek felismerésre, és kiküszöbölésük érdekében nem történik meg a gyakorlat megváltoztatása a hasonló események elkerülésére.

\section{Kommunikációs és dokumentációs problémák}

A pontatlan, hiányos, kései vagy nem a célszemélynek szóló információátadás a szükséges tevékenységek elmaradásához, félreértelmezéséhez vagy helytelen elvégzéséhez vezethet. A nem empatikus kommunikáció agressziót, szökést válthat ki a betegekből, vagy eltéríthetik attól, hogy az adott intézményben vegyen igénybe ellátást.

\section{Oktatás (beteg és dolgozó)}

A napi múködési és szakmai gyakorlat készségszintú ismerete elengedhetetlen a hibátlan munkavégzéshez. Ennek elérésében az oktatásnak nagy szerepe van, így elmaradása, hiányosságai okai lehetnek annak, ha egy tevékenység nem vagy nem jól valósul meg, beleértve a kommunikációt, az eszközhasználatot és a szakmai és múködési folyamatok végrehajtását. Nemcsak a dolgozók oktatásának van jelentősége, hanem a betegek okta- tásának is. A kellő ismeretekkel rendelkező beteg együttmúködővé válik, megérti saját kockázatait és teendőit a nemkívánatos események elkerülése érdekében.

\section{Humánerőforrás-problémák}

A humán erőforrás hiánya vagy nem megfelelő szakmai összetétele általános betegbiztonsági kockázat minden egészségügyi rendszerben. Az oki kutatások mindegyikében megjelent kiváltó okként, akár úgy, hogy nem alkalmaznak megfelelően felkészült munkaerőt - például a dolgozók bántalmazását megelőzendő -, akár úgy, hogy nincs elegendő szakképzett munkatárs a feladat ellátásához - például a nyomási fekély prevenciós feladatainak ellátáshoz.

\section{Eszközhasználat}

Megfelelő prevenciós vagy segédeszközök hiányában megnő a nyomási fekély kialakulásának vagy a betegségek előfordulásának esélye. Az éles-hegyes eszközök szabványostól eltérő gyứjtőedényben történő tárolása könnyen sérüléshez vezet. A nem megfelelő méretű gumikesztyú használata rontja a manipulációt. Az alkalmazandó eszközök hibája komolyan veszélyezteti az újraélesztés megfelelő végrehajtását.

\section{Infrastruktúra}

A rosszul kialakított infrastruktúra - zsúfolt kórterem, a nővérpult és a kórtermek közötti távolság, a közlekedést nehezítő tényezők korlátozzák az ápolási munkát, de növelik például az esések kockázatát, és késleltetik az újraélesztő team helyszínre érkezését.

\section{A problémák kezelésének lebetôségei}

A feltárt okokra támaszkodó lehetséges megoldások több különböző ok kezelésére is alkalmasak lehetnek [17] (3. táblázat).

A szabályozók kialakításának módja befolyásolja a későbbi alkalmazási hajlandóságot, így javasolt már a kidolgozás során bevonni a majdani alkalmazókat. A széles körü bevezetés előtti kipróbálás elősegíti a mindenki számára értelmezhető, végrehajtható elvárások megfogalmazását.

Fontos az elkészült szabályozó formai megjelenése is: a rövid, tömör, egyértelmú megfogalmazás segíti a megértést, a felelősök egyértelmű meghatározása pedig a végrehajtást.

A dolgozói és betegoktatások esetén meg kell határozni a témakört és a célcsoportot, és annak megfelelően kell kialakítani a tananyagot. A módszertannak illeszkednie kell a célcsoport készségeihez és az elsajátítandó ismeretekhez. Az oktatást végző munkatársnak megfelelő képességekkel kell rendelkeznie. Az ismeretek átadását 


\begin{tabular}{|c|c|c|}
\hline $\begin{array}{l}\text { Kezelési javaslat a } \\
\text { 2. táblázatban szerepló okok } \\
\text { sorszámaival }\end{array}$ & Feladatok & A végrehajtás szempontjai \\
\hline \multirow{6}{*}{$\begin{array}{l}\text { a) A szabályozások } \\
\text { kialakításával és a } \\
\text { gyakorlati alkalmazás } \\
\text { elérésével kapcsolatos } \\
\text { teendók: } \\
\text { 1., 2., 3., 4., 5., 6., } 8 \text {. }\end{array}$} & $\begin{array}{l}\text { A szabályozandó területek } \\
\text { azonosítása }\end{array}$ & $\begin{array}{l}\text { A hiányzó szabályozók elkészítése, } \\
\text { a hiányzó tevékenységek beemelése a szabályokba, } \\
\text { a feladatok felelőseinek azonosítása }\end{array}$ \\
\hline & $\begin{array}{l}\text { Az érvényesség és az } \\
\text { egyértelmúség biztosítása }\end{array}$ & $\begin{array}{l}\text { A külső szabályozók folyamatos nyomon követése, } \\
\text { dokumentumtérkép összeállítása a szabályozók érvényességének és kapcsolódási } \\
\text { pontjainak feltüntetésével, } \\
\text { az érintett szabályok aktualizálása, } \\
\text { a szabályok közötti ellentmondások feloldása módosítással }\end{array}$ \\
\hline & A szabályozók elkészítése & $\begin{array}{l}\text { A szabályozóval érintett munkafolyamatok képviselőinek bevonása az elkészítésbe, } \\
\text { tesztelés, } \\
\text { oktatás, } \\
\text { a szükséges feltételek biztosítása (eszköz, anyag, humánerőforrás stb.), } \\
\text { elegendő idő a napi gyakorlatban való alkalmazáshoz való felkészülésre }\end{array}$ \\
\hline & Ellenőrzés és visszacsatolás & $\begin{array}{l}\text { A szabályozás betartásának és betarthatóságának rendszeres felmérése, } \\
\text { szükség esetén a szabály vagy a felelőss személy módosítása vagy a végrehajtás } \\
\text { feltételeinek folyamatos biztosítása, } \\
\text { visszajelzés a szabályozásban érintetteknek a munkavégzés megfelelőségéről, } \\
\text { a szükséges korrekciókról }\end{array}$ \\
\hline & Példamutatás & Vezetői példamutatás a szabályok szerinti munkavégzésben \\
\hline & $\begin{array}{l}\text { A szabályozó formai } \\
\text { megjelenése }\end{array}$ & $\begin{array}{l}\text { Rövid, tömör, érthető megfogalmazás, } \\
\text { logikus felépítés, } \\
\text { a felelősök, helyszínek, időpontok, dokumentálási kötelezettségek egyértelmú } \\
\text { megjelenítése, } \\
\text { lehetőség szerint döntési algoritmus, folyamatábra alkalmazása }\end{array}$ \\
\hline \multirow[t]{3}{*}{$\begin{array}{l}\text { b) Az oktatás megszerve- } \\
\text { zése és lebonyolítása: } \\
\text { 1-9. }\end{array}$} & $\begin{array}{l}\text { A szakmai tartalom meghatá- } \\
\text { rozása }\end{array}$ & $\begin{array}{l}\text { Az érintettek körének meghatározása, } \\
\text { az oktatási szükségletek azonosítása, } \\
\text { az oktatási cél megfogalmazása, } \\
\text { a tananyag kidolgozása, beleértve az ismeretanyag gyakorlati alkalmazásának } \\
\text { fontosságát, } \\
\text { az oktatási módszertan meghatározása a célcsoportoknak megfelelően }\end{array}$ \\
\hline & Az oktatás megszervezése & $\begin{array}{l}\text { Képzett oktató felkérése, } \\
\text { az érintettek értesítése, } \\
\text { a jelenlét biztosítása, } \\
\text { a feltételek biztosítása (terem, oktatástechnika, ápolási, orvosi eszközök stb.) }\end{array}$ \\
\hline & Visszamérés & $\begin{array}{l}\text { A képzésben részt vettek tudásellenőrzése, } \\
\text { visszacsatolás (oktató, tananyag, oktatási módszertan, elért tudás) }\end{array}$ \\
\hline $\begin{array}{l}\text { c) Beszerzés a szükségletek } \\
\text { alapján: 1., 6., 7., 8., } 9 \text {. }\end{array}$ & $\begin{array}{l}\text { A szükséges eszközök } \\
\text { azonosítása }\end{array}$ & $\begin{array}{l}\text { Az eszközöket használó munkatársak bevonása a beszerzendő eszközök specifiká- } \\
\text { lásába }\end{array}$ \\
\hline \multirow[t]{3}{*}{$\begin{array}{l}\text { d) A kommunikáció } \\
\text { fejlesztése: } \\
1 ., 4 ., 5 ., 7 \text {. }\end{array}$} & $\begin{array}{l}\text { Kommunikációs módszerek } \\
\text { alkalmazása, a kapcsolódó } \\
\text { szabályozók kialakítása }\end{array}$ & $\begin{array}{l}\text { Az ellenőrző listákra, információátadási technikákra (például SBAR, ISOBAR) } \\
\text { [10] vonatkozó szabályozók kialakítása, oktatása, gyakoroltatása, valamint } \\
\text { alkalmazásuk elvárása és nyomon követése }\end{array}$ \\
\hline & Kommunikációs tréningek & $\begin{array}{l}\text { A kommunikációs készségek fejlesztése a dolgozók, illetve a dolgozók és } \\
\text { a betegek, hozzátartozóik között }\end{array}$ \\
\hline & Csapatépítő tréningek & $\begin{array}{l}\text { A különböző munkaköri csoportok, osztályok együttmúködésének fejlesztése, } \\
\text { a csapatban dolgozók valódi csapattá fejlesztése }\end{array}$ \\
\hline $\begin{array}{l}\text { e) Tanulás a hibákból, } \\
\text { nemkívánatos események- } \\
\text { ből: } 4 \text {. }\end{array}$ & $\begin{array}{l}\text { A jelentési és tanulórendszer } \\
\text { múködtetése }\end{array}$ & $\begin{array}{l}\text { Saját jelentési rendszer kialakítása vagy csatlakozás külső rendszerhez, } \\
\text { esetszintű és/vagy aggregált oki kutatás végzése, } \\
\text { buzdítás a jelentések megtételére és az őszinte helyzetfeltárásra, } \\
\text { „miért” kérdésekkel történő oki vizsgálat „ki” helyett, } \\
\text { intézkedések a feltárt okokra támaszkodó megoldások alapján, } \\
\text { visszajelzés a munkatársaknak }\end{array}$ \\
\hline \multirow{3}{*}{$\begin{array}{l}\text { f) Motivációs eszközök } \\
\text { alkalmazása: } \\
\text { 1., } 4 ., 7 .\end{array}$} & Megértés és megértetés & $\begin{array}{l}\text { Nyílt és őszinte kommunikáció a lehetséges betegbiztonsági problémákról, } \\
\text { a szükséges változások indokoltságáról és várható eredményeiről }\end{array}$ \\
\hline & Példamutatás & $\begin{array}{l}\text { A szabályok szerinti munkavégzés a döntéshozók, vezetók részéről, } \\
\text { őszinteség az egyes események megbeszélése kapcsán }\end{array}$ \\
\hline & Értékelés és elismerés & $\begin{array}{l}\text { Buzdítás az események jelentésére, az őszinte esetfeltárásra, } \\
\text { a betegbiztonságért tett intézkedések ösztönzése és elismerése }\end{array}$ \\
\hline
\end{tabular}

ISOBAR = (identify, situation, observations, background, agreed plan, read back) azonosítás, helyzet, megfigyelések, háttér, elfogadott terv, viszszaolvasás; SBAR = (situation, background, assessment, recommendation $)$ helyzet, háttér, értékelés, ajánlás 
követően a tudás visszaellenőrzésével lehet meggyőződni arról, hogy a résztvevők tudják-e majd azokat alkalmazni a gyakorlatban.

A kommunikáció javításában jelentős szerepe van azon módszerek alkalmazásának, amelyek segítik az emlékezést (feladatlisták, ellenőrző listák) és a szükséges információk releváns módon történő átadását. A megfelelő alkalmazáshoz kellő oktatásra, gyakorlásra, monitorozásra van szükség. Segítséget ad a kommunikáció javításában a készséget fejlesztő tréningek lebonyolítása. A csapatmunka javításában a csapatépítő tréningeknek van kiemelt szerepük.

Az előfordult hibákból, nemkívánatos eseményekből való tanuláshoz - a vezetői támogatás és elkötelezettség mellett - az alkalmazandó módszereket jól ismerő, készségszinten alkalmazni tudó munkatársakra van szükség. Az elemzésekhez, oki kutatások lebonyolításához a megtörtént esetekkel kapcsolatos információk gyújtése szükséges. Biztosítani kell a munkatársakat, hogy az elemzések őszinte légkörben, szankciómentes módon zajlanak. Az okok feltárása mellett olyan intézkedések meghozatalára van szükség, amelyek képesek a kiváltó okok szerepét csökkenteni, és a gyakorlatban alkalmazásra is kerülnek.

Minden elvárás alkalmazási foka, a változtatások gyakorlatba ültetésének készsége és az alkalmazás eredményessége a dolgozók változtatási készségén és képességén múlik. Az erre való motiválás jelentheti a változás szükségességének megértetését, példamutatást, a munkavégzés értékelését és visszajelzését, valamint pozitív ösztönzők kialakítását és alkalmazását a napi gyakorlatban.

\section{Megbeszélés}

A nemkívánatos esemény (adverse event) olyan károsodást (harm) - időleges vagy tartós egészségkárosodást, életminőség-romlást vagy halált - jelent a beteg számára, amely az ellátás következményeként lép fel, azaz nem a természetes biológiai folyamatok eredménye. A nemkívánatos esemény megelözhetō, ha azonosítható az ellátás során az eseményt megelőzően bekövetkezett olyan tervezési vagy végrehajtási hiba, illetve környezeti tényezó, amelynek előfordulása nélkül az esemény nem jött volna létre. Hibázáskor ugyanakkor nem feltétlenül alakul ki nemkívánatos esemény. Az egészségügyben a nemkínánatos események $\mathrm{kb}$. 70\%-a lenne megelözheto", azaz a kialakult ártalom az esetek 70\%-ában vezethető vissza az ellátás gyengeségeire, hibáira $[1,5,18]$.

A nemkívánatos eseményeket okozó hibákat az esetek többségében emberek követik el; ritkábban gépek, eszközök vagy egyéb környezeti tényezők a hibaforrások. Az emberi hibák mögött ugyanakkor általában olyan tervezési és/vagy szervezési hiányosságok állnak, amelyek hibázásra hajlamosítják a dolgozókat [19]. Kevés kutatás van, amely azt vizsgálja, hogy a megelőzhető nemkívánatos események hány százalékáért felelősek csupán a hibát elkövető személyek. Egy 2012-ben publikált tanulmány [20] arra is rávilágít, hogy a kutatók még mindig az emberi hibákra fókuszálnak, és kevéssé vizsgálják az emberi hibák szervezeti szintû mögöttes okait, így az ilyen eredmények kevéssé fogadhatók el megbízható adatként, és kevésbé alkalmasak a hatásos prevenciós intézkedések meghatározásához. Reason [21] egy ausztrál tanulmányt idéz, amely szerint a megelőzhető nemkívánatos események 90\%-a esetében azonosítottak szervezeti szintü hiányosságokat, így csak az események 10\%-ában állapítható meg csupán személyi felelősség.

Az ellátás során bekövetkező, hasonló típusú nemkívánatos események hátterében hasonló okok és körülmények húzódnak meg. Amíg ezek az okok és körülmények fennállnak a tevékenységek elvégzése során, nagy valószínúséggel ismételten elő fognak fordulni a hibák és a negatív következmények is. A hibák, nemkívánatos események mögöttes okainak feltárása lehetőséget nyújt ahhoz, hogy kiküszöbölésükkel, jelentőségük mérséklésével csökkentsük a hasonló események ismételt előfordulásának lehetőségét. Ehhez nyújt segítséget a bekövetkezett események jelentése, összegyújtése és az adatok alapján olyan közös mintázatok keresése, amelyek felhívják a figyelmet a beavatkozást igénylő területekre [ 1,3 , 5]. A jelentési rendszerek ugyanakkor nem alkalmasak az előfordult események gyakoriságának meghatározására, ami többek között az önkéntességból, az anonimitásból, az aluljelentésből [5] és abból származik, hogy nem ismert azon érintettek száma, akik közül a jelentett események kikerülnek. A jelentések ezért arra alkalmasak, hogy vizsgáljuk az előfordulás körülményeit, szereplőit, időpontjait stb., és erre támaszkodva keressük a kiváltó okokat.

A bekövetkezett eseményekből való tanulás a gyökérokelemzésen (root cause analysis - RCA) alapul. Az RCA retrospektív technika, célja az eseményt előidéző okok megismerése, és az ezekre támaszkodó intézkedési javaslatok megfogalmazása az ismétlődések elkerülésére. Aggregált RCA során nagyobb számú, azonos típusú eseményt vizsgálva megismerhetjük az adott események természetét, és feltárhatjuk az azok kialakulásához vezető legfontosabb okokat. Annak érdekében, hogy a bekövetkezett eseményekról feldolgozható információk álljanak rendelkezésre, szisztematikus adatgyújtést kell végezni, amit a leginkább jelentési rendszer segítségével lehet megvalósítani $[8,9,22]$.

Az aggregált oki kutatás statisztikailag elemezhető esetszám meglétét feltételezi. Ennek összegyưjtéséhez - az adott esemény előfordulási gyakoriságától függően - intézményi szinten általában hosszabb idő szükséges, ami késlelteti - vagy az időközben bekövetkező változások miatt-ellehetetleníti az eredményes intézkedések meghozatalát. Emellett az intézmények általában nem rendelkeznek azokkal az elemzési készségekkel, amelyek alapján szisztematikus oki kutatást tudnak végezni. Az országosan gyüjtött jelentések feldolgozása és visszajelzése a szolgáltatók számára ebből eredően hasznos tá- 
mogatás lehet a jelentett események előfordulásának visszaszorításához.

A jelentések gyűjtése önmagában nem elégséges a káros események előfordulási gyakoriságának csökkentéséhez. A jelentések feldolgozását követően olyan intézkedések megfogalmazására van szükség, amelyeket a gyakorlatba be lehet vezetni, és azok meg is valósulnak. A sikert jelentôs mértékben befolyásolja az adott intézmény szervezeti kultúrája [5].

A szervezeti kultúra az egy szervezetben dolgozók „közösen értelmezett előfeltevéseinek, értékeinek, meggyőződéseinek és hiedelmeinek rendszere" [23]. Az egy szervezeti kultúrához tartozók a kialakult közös gondolkodási keretet és értékrendet érvényesnek fogadják el, követik, és a szervezet új tagjai számára is átadják.

Bámelyik szervezetre igaz, hogy a múködésében meglévő veszélyeket és kockázatokat inkább felismerik és kezelik, ha sikerül kialakítani és fenntartani a biztonságot támogató szervezeti kultúrát. Mindez az egészségügyi intézményekre értelmezve a betegbiztonságot támogató szervezeti kultúra jelenlétét feltételezi. Ennek főbb jellemzői a kölcsönös bizalmon alapuló kommunikáció, a biztonság jelentőségét elismerő közös gondolkodásmód és az eredményesen alkalmazott megelőző intézkedések. $\mathrm{Az}$ ilyen intézményekben a munkatársak szóvá teszik a kockázatos helyzeteket és magatartásformákat, követik a biztonságos múködés szempontjából kritikus szabályokat, és a müködés biztonságosságát helyezik előtérbe a kibocsátás volumenével szemben. Ennek elérésében kiemelt szerepe van annak, hogy a vezetés mennyiben veszi figyelembe a tervezéskor az emberi hibákat provokáló tényezőket, hogyan segítik elő a nemkívánatos események és a hibák okainak szisztematikus feltárását a jelentési rendszerek múködtetésével, aktív szereplői-e a betegbiztonsági képzéseknek, példaadással motiválják-e a munkatársakat a szabályok szerinti munkavégzésre, bátorítják-e a teammunkát és az őszinte, nyílt kommunikációt [24-26]. Hazánkban 2015-ben hazai kórházakban Lám és mtsai [26] felmérték a szervezeti kultúra érettségi szintjét a betegbiztonság szempontjából. Eredményeik alapján megállapítható, hogy az intézmények érettsége lényegesen kedvezőtlenebb az ajánlottnál, és különösen alacsony szinten áll a nem büntető reagálásnak, a kommunikáció nyíltságának és a betegbiztonság általános észlelésének területén. 2017-ben a Debreceni Egyetem Klinikai Központjában és 2018-ban egy nemzetközi kutatás keretében három magyar kórházban történt hasonló felmérés, amelyek során hasonló eredmények születtek $[27,28]$.

A NEVES rendszerbe érkezett jelentések alapján megfogalmazott okok a szervezeti múködés általános gyengeségeinek is tekinthetők, hisz a szabályozás vagy a szabálykövetés hiánya, az oktatások megszervezésének és lebonyolításának gyengeségei, a kommunikáció elégtelensége vagy az eseményekből való tanulás hiánya nem egy-egy nemkívánatos eseményre specifikusak, hanem általános múködési problémaként, az intézményekben kialakult szokásként, kulturális elemként értelmezhetők. Ebből következően a javasolt megoldások implementációjával nem csupán egy-egy nemkívánatos esemény előfordulásának mérséklését lehet elérni, hanem általában csökkenhet a hibák és ebból fakadóan a nemkívánatos események gyakorisága.

Eredményeinket nemzetközi kutatások eredményeivel is összevetettük. Holland kórházakban végzett elemzések alapján megállapították, hogy az emberi tényezőkre visszavezethető hibák körülbelül felét a dolgozók nem megfelelő ismerete okozta, míg a szervezeti tényezőkre visszavezethető hibák esetén a leginkább a nem megfelelő protokoll megléte és az új dolgozók felé történő nem megfelelő tudásátadás állt a háttérben $[29,30]$. A nem megfelelő beteg és anyag azonosítása, az ellátóteam koordinációjának hiánya, a nem megfelelő szervezeti kultúra és a rossz menedzsmenti prioritások is megjelentek okként, ezek viszont a két holland kutatásban nem mutattak egységes képet. Hongkongi kórházakban is hasonló elemzéseket csináltak, viszont a gyökérokkutatás során más osztályozási rendszert alkalmaztak [31]. Eredményül azt kapták, hogy az esetek harmada arra vezethető vissza, hogy a személyzet nem követte az elóírásokat és a szakmai irányelveket, és jelentős okként jelent meg, hogy nem voltak megfelelőek a képzések, nem megfelelő a létszám, illetve nem megfelelő a kommunikáció. Hasonló következtetéseket fogalmazott meg egy spanyol tanulmány, amely a kommunikációs problémákat, a protokollok vagy használatuk hiányát és a szervezeti kultúra problémáit említi a nemkívánatos események legfontosabb okaként [32].

A jelenlegi kutatás eredményei nagy átfedést mutatnak mind a holland, mind a hongkongi kutatások eredményeivel. A pontos összehasonlítást azonban nehezíti, hogy a gyökérokok csoportosítására más módszert használtak, valamint sok esetben nem valódi gyökérokról írnak a nemzetközi tanulmányok - például nem vizsgálták tovább, hogy a nem megfelelő azonosítás milyen okokra vezethető vissza [29-31]. Összességében a külföldi tanulmányok is megerősítik a saját tanulmányunkban is megfogalmazott javaslatokat: megfelelő szabályozások kialakítása és alkalmazása, az egészségügyi személyzet oktatása és a szervezeten belüli kommunikáció erősítése segítheti elő a hibák és a nemkívánatos események visszaszorítását.

A talált okok az országos jelentések alapján kerültek meghatározásra, így az intézmények saját jellemzőik alapján tudják a helyi okokat azonosítani és a megvalósítható intézkedéseket meghatározni. Nemzetközi kutatások igazolják, hogy a módszertan alkalmazásával és a megfogalmazott ajánlások implementálásával mérhető javulást lehet elérni a betegbiztonság terén. Két tajvani kórházban a szülés utáni betegesések mértékét csökkentették a kismamák körében gyökérokelemzésre alapozott intézkedésekkel [33]. Egy holland egyetemi kórházban a mútétet követő halálozási arány javult az oki kutatást követő változtatások eredményeként [34]. Egy máltai kór- 
házban a nyomási fekély kialakulásának arányát csökkentették [35], egy tajvani egyetemi kórházban az újszülöttek gyógyszerelését sikerült biztonságosabbá tenni [36].

Az elemzés korlátai között említendő, hogy abból fakadóan, hogy a jelentések önkéntesek és anonimak, nem lehet tudni, reprezentálják-e az intézményeket és az előfordult eseményeket. Emellett nem vizsgálható a jelentések valóságtartalma, és az egyes esetek részletesebb megismerése érdekében nem volt lehetőség további információ szerzésére. A beküldött jelentések száma az események gyakoriságának és a jelentési hajlandóságnak a függvénye, mivel azonban a feltárt okok között fontossági sorrendet nem állítottunk fel, eredményeinket az eltérő esetszámok nem befolyásolják. A jelentési rendszerekbe érkező információk tanulórendszerként való használata hozzájárul a betegbiztonság javulásához. A kapott eredmények terjesztése elősegíti, hogy a munkatársak megértsék a jelentések fontosságát és hasznosságát, ezen keresztül javuljon a jelentési fegyelem és a közzétett ajánlások implementációs hajlandósága [5].

Anyagi támogatás: A dolgozat alapjául szolgáló kutatások az Európai Unió által támogatott EFOP-1.8.0VEKOP-17 kiemelt pályázati konstrukció keretében készültek. A publikáció megírása anyagi támogatás nélkül történt.

Szerzői munkamegosztás: B. É.: A dolgozat alapjául szolgáló kutatások elméleti irányítása, a dolgozat szakmai tartalmának kialakítása, a végső változat elkészítése. D. V.: A nemzetközi szakirodalom áttekintése és szintézise, közremúködés a szakmai tartalom összeállításában. M. G.: Az oki kutatások eredményeinek szintetizálása. S. L. A. E.: A dolgozat alapjául szolgáló kutatások irányítása, közremúködés a dolgozat szakmai tartalmának öszszeállításában. A dolgozat végleges változatát valamenynyi szerző elolvasta és jóváhagyta.

Érdekeltségek: A szerzőknek nincsenek érdekeltségeik.

\section{Köszönetnyilvánítás}

Köszönetünket fejezzük ki a NEVES jelentési rendszerbe jelentő öszszes intézménynek és kollégának, valamint az oki kutatásokban közremúködő szakértőknek, különösen a következő munkatársaknak: Grézló Orsolya, Magyar-Berényi Annamária, Megléczné Ocsenás Mária, Pató Edit, Pitás Eszter, Valasek-Vincze Ildikó.

\section{Irodalom}

[1] Kohn LT, Corrigan JM, Donaldson MS. (eds.) To err is human. Building a safer health system. Institute of Medicine (US) Committee on Quality of Health Care in America. National Academies Press, Washington, DC, 2000.

[2] Public Law 109-41 - July 29, 2005. 109th Congress on Patient Safety and Quality Improvement Act of 2005. Available from: https://www.congress.gov/109/plaws/publ41/PLAW109publ41.pdf [accessed: July 9, 2021].
[3] World Health Organization. World alliance for patient safety: WHO draft guidelines for adverse event reporting and learning systems: from information to action. WHO, Geneva, 2005. Available from: https://apps.who.int/iris/handle/10665/ 69797 [accessed: July 9, 2021].

[4] Council recommendation of 9 June 2009 on patient safety, including the prevention and control of healthcare associated infections. Official Journal of the European Union, 2009; C 151/01. Available from: https://eur-lex.europa.eu/legalcontent/EN/TXT/PDF/?uri=CELEX:32009H0703(01)\&fro m=en [accessed: July 9, 2021].

[5] World Health Organization. Patient safety incident reporting and learning systems: technical report and guidance. WHO, Geneva, 16 September 2020. Available from: https://www. who.int/publications-detail-redirect/9789240010338 [accessed: July 9, 2021].

[6] Belicza É, Kullmann L. Patient safety program implementation in Hungary - NEVES (incidents). [Betegbiztonsági program hazai megvalósítása - NEVES (nem várt események).] Kórház 2008; 3: 32-35. [Hungarian]

[7] Lám J, Sümegi V, Surján C, et al. Role of reporting and learning systems in the improvement of patient safety. [A jelentési és tanulórendszerek szerepe a betegbiztonság javításában.] Orv Hetil. 2016; 157: 1035-1042. [Hungarian]

[8] Sinka LAE, Pitás E, Belicza É. Methodological guide for root cause research. [Módszertani útmutató az oki kutatások készítéséhez.] Semmelweis Egyetem, Egészségügyi Menedzserképző Központ, Budapest, 2019. [Hungarian]

[9] Neily J, Ogrinc G, Mills P, et al. Using aggregate root cause analysis to improve patient safety. Jt Comm J Qual Saf. 2003; 29: 434-439.

[10] Dombrádi V, Grézló O, Sinka LAE, et al. Causes of patient wandering and absconding, and possible methods to prevent them. [A betegek elkóborlásának és önkényes távozásának okai, illetve a megelőzés lehetőségei.] Semmelweis Egyetem, Egészségügyi Menedzserképző Központ, Budapest, 2020. [Hungarian]

[11] Mikesy G, Sinka LAE, Belicza É. Causes of elective surgical case cancellation and possible methods to prevent them. [Az elmaradt tervezett mútétek okai és a megelőzés lehetőségei.] Semmelweis Egyetem, Egészségügyi Menedzserképző Központ, Budapest, 2020. [Hungarian]

[12] Pató E, Dombrádi V, Megléczné Ocsenás M, et al. Causes of pressure ulcers and possible methods to prevent them. [A nyomási fekély kialakulásának okai és a megelőzés lehetôségei.] Semmelweis Egyetem, Egészségügyi Menedzserképző Központ, Budapest, 2020. [Hungarian]

[13] Pató E, Magyar-Berényi A, Sinka LAE, et al. Deficiencies in the operation of the resuscitation chain, their causes and possible solutions. [Az újraélesztési lánc múködtetésének hiányosságai, ezek okai és megoldási lehetőségei.] Semmelweis Egyetem, Egészségügyi Menedzserképző Központ, Budapest, 2020. [Hungarian]

[14] Sinka LAE, Pató E, Nemesné Singer E, et al. Causes of sharps injuries and possible methods to prevent them. [Éles, hegyes eszközök okozta sérülések okai, a megelőzés lehetősége.] Semmelweis Egyetem, Egészségügyi Menedzserképző Központ, Budapest, 2020. [Hungarian]

[15] Valasek-Vincze I, Belicza É, Sinka LAE. Causes of worker abuse and possible methods to prevent them. [A dolgozók bántalmazásának okai és a megelőzés lehetőségei.] Semmelweis Egyetem, Egészségügyi Menedzserképző Központ, Budapest, 2020. [Hungarian]

[16] Valasek-Vincze I, Megléczné Ocsenás M, Sinka LAE, et al. Causes of patient falls and possible methods to prevent them. [A betegek esésének okai és megelőzési lehetőségei.] Semmelweis Egyetem, Egészségügyi Menedzserképző Központ, Budapest, 2020. [Hungarian] 
[17] Belicza É, Lám J. (eds.) Patient safety in practice. [Betegbiztonság a gyakorlatban.] Semmelweis Egyetem, Egészségügyi Menedzserképző Központ, Budapest, 2021. [Hungarian]

[18] Jha AK, Larizgoitia I, Audera-Lopez C, et al. The global burden of unsafe medical care: analytic modelling of observational studies. BMJ Qual Saf. 2013; 22: 809-815.

[19] Carthey J, Clarke J. Implementing human factors in healthcare. 'How to' guide. National Health Service, London, 2009.

[20] Lawton R, McEachan RR, Giles SJ, et al. Development of an evidence-based framework of factors contributing to patient safety incidents in hospital settings: a systematic review. BMJ Qual Saf. 2012; 21: 369-380.

[21] Reason J. Safety in the operating theatre - Part 2. Human error and organisational failure. Qual Saf Health Care 2005; 14: 5660.

[22] Taitz J, Genn K, Brooks V, et al. System-wide learning from root cause analysis. Qual Saf Health Care 2010; 19: e63.

[23] Bakacsi Gy. The basics of organizational behavior. [A szervezeti magatartás alapjai.] Semmelweis Kiadó, Budapest, 2015. [Hungarian]

[24] Sammer CE, Lykens K, Singh KP, et al. What is patient safety culture? A review of the literature. J Nurs Scholarsh. 2010; 42: $156-165$.

[25] Halligan M, Zecevic A. Safety culture in healthcare: a review of concepts, dimensions, measures and progress. BMJ Qual Saf. 2011; 20: 338-343

[26] Lám J, Merész G, Bakacsi Gy, et al. Changing of the patient safety culture in the pilot institutes of the Hungarian accreditation program. [A betegbiztonságot támogató szervezeti kultúra változása a hazai akkreditációs programot tesztelő intézményekben.] Orv Hetil. 2016; 157: 1667-1673. [Hungarian]

[27] Hemaid N, Dombrádi V, Gáll T, et al. Surveying and assessing the patient safety culture within the University of Debrecen Clinical Centre. [A betegbiztonsági kultúra felmérése és elemzése a Debreceni Egyetem Klinikai Központjában.] IME 2019; 18: 19-22. [Hungarian]

[28] Lám J, Safadi H, Pitás E, et al. Who knows what? - About patient handover experiences of a Hungarian and Polish sample knowl- edge survey. [Ki mit tud? - A betegátadásról. Egy magyar és lengyel mintán végzett tudásfelmérés tapasztalatai.] Orv Hetil. 2019; 160: 1735-1743. [Hungarian]

[29] Smits M, Zegers M, Groenewegen PP, et al. Exploring the causes of adverse events in hospitals and potential prevention strategies. Qual Saf Health Care 2010; 19: e5.

[30] Hooker AB, Etman A, Westra M, et al. Aggregate analysis of sentinel events as a strategic tool in safety management can contribute to the improvement of healthcare safety. Int J Qual Health Care 2019; 31: 110-116.

[31] Kwok YT, Mah AP, Pang KM. Our first review: an evaluation of effectiveness of root cause analysis recommendations in Hong Kong public hospitals. BMC Health Serv Res. 2020; 20: 507.

[32] Guerra-García MM, Campos-Rivas B, Sanmarful-Schwarz A, et al. Description of contributing factors in adverse events related to patient safety and their preventability. [Descripción de factores contribuyentes en sucesos adversos relacionados con la seguridad del paciente y su evitabilidad.] Aten Primaria 2018; 50: 486492. [Spanish]

[33] Chen KH, Chen LR, Su S. Applying root cause analysis to improve patient safety: decreasing falls in postpartum women. Qual Saf Health Care 2010; 19: 138-143.

[34] Kievit J, Krukerink M, Marang-van de Mheen PJ. Surgical adverse outcome reporting as part of routine clinical care. Qual Saf Health Care 2010; 19: e20.

[35] Abela G. Root cause analysis to identify contributing factors for the development of hospital acquired pressure injuries. J Tissue Viability 2021; 30: 339-345.

[36] Chien CH, Yang YL, Fann GL. Applying root cause analysis to promote the medication safety of continuous drug infusions for infants. Hu Li Za Zhi 2014; 61(2 Suppl): S14-S23. [Chinese]

(Belicza Éva dr., Budapest, Pf. $601 . ; 1539$ e-mail: belicza.eva@emk.semmelweis.hu)

\title{
Háziorvosi praxis eladó
}

\author{
Móron 1500 kártyával, felnőttkörzet eladó. \\ Érdeklődni lehet: +36 70/26-20-977
}

A cikk a Creative Commons Attribution 4.0 International License (https://creativecommons.org/licenses/by/4.0/) feltételei szerint publikált Open Access közlemény, melynek szellemében a cikk bármilyen médiumban szabadon felhasználható, megosztható és újraközölhető, feltéve, hogy az eredeti szerző és a közlés helye illetve a CC License linkje és az esetlegesen végrehajtott módosítások feltüntetésre kerülnek. (SID_1) 